
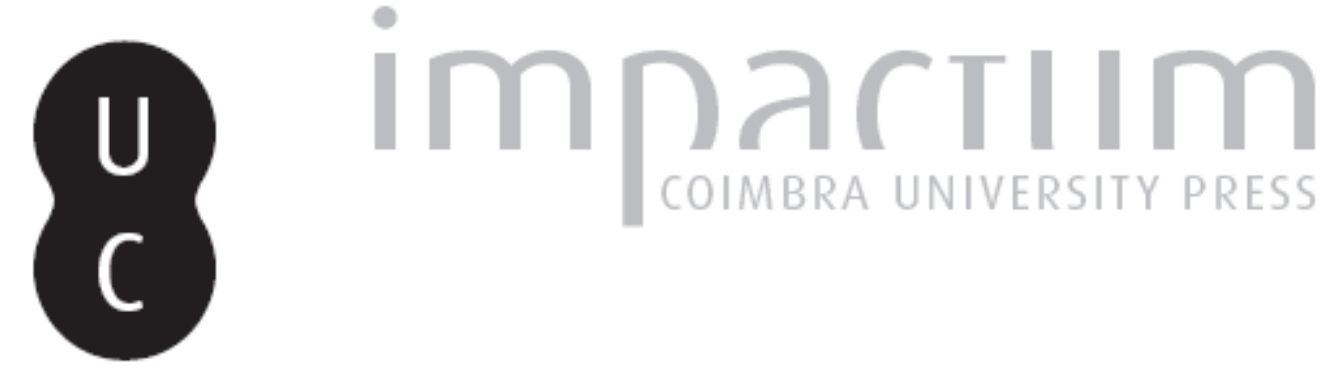

\title{
O risco climático da seca no semiárido brasileiro
}

Autor(es): $\quad$ Ramalho, Maria Francisca de Jesus Lírio; Guerra, Antonio José Teixeira

Publicado por: Imprensa da Universidade de Coimbra

URL persistente:

URI:http://hdl.handle.net/10316.2/43272

DOI:

DOI:https://doi.org/10.14195/1647-7723_25-1_5

Accessed : $\quad$ 26-Apr-2023 13:25:26

A navegação consulta e descarregamento dos títulos inseridos nas Bibliotecas Digitais UC Digitalis, UC Pombalina e UC Impactum, pressupõem a aceitação plena e sem reservas dos Termos e Condições de Uso destas Bibliotecas Digitais, disponíveis em https://digitalis.uc.pt/pt-pt/termos.

Conforme exposto nos referidos Termos e Condições de Uso, o descarregamento de títulos de acesso restrito requer uma licença válida de autorização devendo o utilizador aceder ao(s) documento(s) a partir de um endereço de IP da instituição detentora da supramencionada licença.

Ao utilizador é apenas permitido o descarregamento para uso pessoal, pelo que o emprego do(s) título(s) descarregado(s) para outro fim, designadamente comercial, carece de autorização do respetivo autor ou editor da obra.

Na medida em que todas as obras da UC Digitalis se encontram protegidas pelo Código do Direito de Autor e Direitos Conexos e demais legislação aplicável, toda a cópia, parcial ou total, deste documento, nos casos em que é legalmente admitida, deverá conter ou fazer-se acompanhar por este aviso.

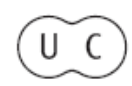


territorium/25w|.

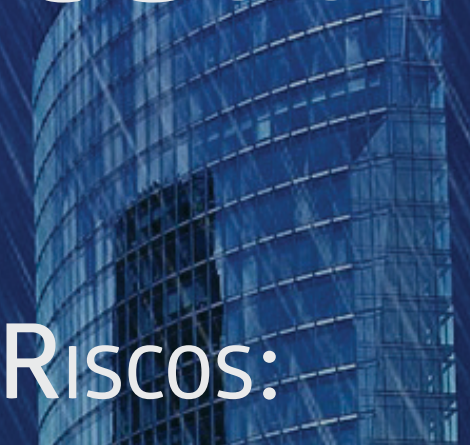

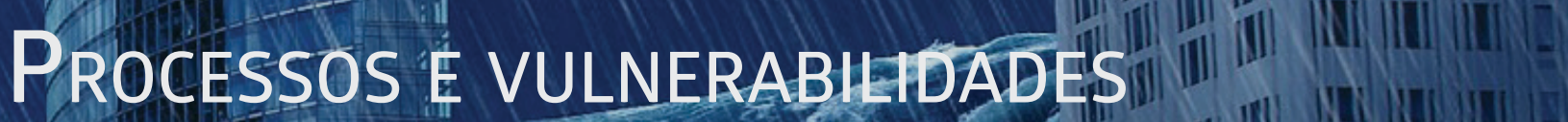

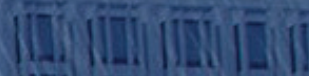
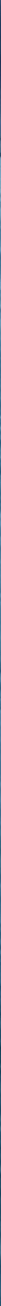

Imprensa da Universidade de Coimbra

Associação Portuguesa de Riscos, Prevenção e Segurança

2018 


\title{
O RISCO CLIMÁTICO DA SECA NO SEMIÁRIDO BRASILEIRO*
}

THE CLIMATIC RISK OF DROUGHT TO THE BRAZILIAN SEMI-ARID REGION

Maria Francisca de Jesus Lírio Ramalho

Departamento de Geografia, Universidade Federal do Rio Grande do Norte (Brasil) franci@ufrnet.br

Antonio José Teixeira Guerra

Departamento de Geografia, Universidade Federal do Rio de Janeiro (Brasil) antoniotguerra@gmail.com

\begin{abstract}
RESUMO
As estiagens e as enxurradas do período chuvoso são fatores de risco de fenômenos meteorológicos e climáticos que caracterizam ambientes semiáridos como o do nordeste do Brasil. 0 presente artigo faz uma breve discussão sobre o risco climático da seca, associando a sazonalidade climática, ações humanas e a vulnerabilidade ambiental à erosão e ao assoreamento de mananciais na Serra do Teixeira, com o exemplo de caso do histórico Açude de Poços, no município de Teixeira (Paraíba). 0 estudo se fundamenta em pressupostos da morfodinâmica do semiárido, observando fatores que são peculiares à Serra do Teixeira, como a irregularidade das precipitações pluviométricas, o regime climático, o relevo fortemente ondulado, as áreas com vegetação degradada, a susceptibilidade erosiva dos solos e o efeito do escoamento nas encostas. Da análise, constata-se que tanto o fator climático como o antrópico são causas de risco ambiental para a região, considerando a alternância de períodos secos com os de chuvas torrenciais, a expansão de áreas de cultivos e o mau uso dos recursos naturais.
\end{abstract}

Palavras-chave: Sazonalidade climática, risco natural, risco ambiental.

\section{ABSTRACT}

Droughts and the floods of the rainy period are risk factors of meteorological and climatic phenomena, which characterize semi-arid environments, like north eastern Brazil. This article addresses the climatic risk of drought, associating climatic seasonality, human actions and environmental vulnerability to erosion and silting of the Teixeira Mountain Range springs, with the example of the historic case of Açude (weir) de Poços, in Teixeira Municipality, Paraíba State. This research work is based on assumptions related to semi-arid morphodynamics, observing factors peculiar to the Teixeira Mountain Range, such as irregular precipitation, climatic regime, steep relief, areas with degraded vegetation, soils prone to erosion and the effect of runoff on the slopes. From the analysis it is verified that both the climatic and the human factors are causes of environmental risk for the region, considering the alternation of dry and torrential rains, the expanse of rural areas and the mismanagement of natural resources.

Keywords: Seasonal climate, natural risk, environmental risk.

\footnotetext{
* O texto deste artigo corresponde a uma comunicação apresentada no III Congresso Internacional, I Simpósio Ibero-Americano e VIII Encontro Nacional de Riscos, tendo sido submetido em 30-06-2016, sujeito a revisão por pares a 15-09-2016 e aceite para publicação em 16-03-2017.

Este artigo é parte integrante da Revista Territorium, n. ${ }^{\circ} 25$ (I), 2018, ${ }^{\circ}$ RIscos, ISSN: 0872-8941.
} 


\section{Introdução}

O semiárido brasileiro abrange porções de áreas de oito estados da região Nordeste (Piauí, Ceará, Rio Grande do Norte, Paraíba, Pernambuco, Alagoas, Sergipe e Bahia), compreendendo, assim, a maior parte do polígono da seca no qual se incluem também o norte do estado de Minas Gerais, localizado na região Sudeste. São 1.135 municípios que fazem parte desse espaço geográfico, de extensão territorial em torno de $980.133,079 \mathrm{~km}^{2}$, onde reside uma população de aproximadamente 22.598,318 habitantes, equivalente a $11,85 \%$ da população brasileira (Instituto Nacional do Semiárido [INSA], 2012).

As principais características dessa região são irregularidade de precipitações pluviométricas, escassez de chuvas e ocorrência de vegetação de caatinga, geralmente com aspecto fisionômico diversificado. Esse aspecto se refere não apenas às variações climáticas regionais ou locais e à composição florística, mas também a outros fatores relacionados com topografia, tipos de solo e impactos de atividades humanas (Melo e Rodrigues, 2004, p. 49).

Deve-se ao naturalista alemão Carl Friederich Philip Von Martius (1840 citado por Melo e Rodrigues, 2004) a primeira definição científica da vegetação conhecida por caatinga (Sylva aestu aphylla). Ele destacou os principais traços da caatinga: “vegetação arborescente, portanto lenhosa (sylva), com perda total das folhas (aphylla) durante a estação seca (aestu)". A interferência antrópica tem sido responsabilizada pelas modificações estruturais, florísticas e ecológicas, que, por vezes, dão origem a núcleos de degradação e desertificação (Melo e Rodrigues, 2004).

Conforme Sá, Cunha, Teixeira, Angelotti e Drumond (2010), as pesquisas realizadas em áreas do semiárido brasileiro demonstram uma realidade de processos negativos sobre a flora e a fauna silvestres, bem como uma estreita ligação desses processos com a atividade antrópica sobre o meio, principalmente sobre os solos, onde os processos erosivos se intensificam e constituem os indícios mais marcantes da desertificação. Acredita-se que as consequências de tais processos em um ambiente vulnerável à seca podem ser severas, tendo-se em conta os fatores de risco de fenómenos meteorológico e climático, uma vez que a região convive com dois tipos de períodos secos: o estacional, que corresponde à estação não chuvosa, com sete a nove meses de duração, denominada verão; e as secas periódicas (Mendes, 1985).

A escassez de água nos reservatórios por causa da seca que ocorre desde o ano de 2012 afetou o desempenho da açudagem, causando repercussão em muitos sistemas de abastecimento de água no semiárido. Em períodos de seca, somam-se os danos que podem ser causados à agricultura, à pecuária e a outros meios de sobrevivência da população; além do problema com o abastecimento de água, destaca-se também a vulnerabilidade ambiental à erosão em períodos de retorno das chuvas.

Em se tratando da dinâmica erosiva do semiárido, discute-se, neste artigo, o risco climático da seca no município de Teixeira analisando-se a vulnerabilidade ambiental à erosão e ao assoreamento de mananciais. 0 Açude de Poços, um dos mais antigos da Serra do Teixeira (1879), é um exemplo entre os açudes que secam com a estiagem, desfavorecendo o abastecimento de água e as culturas irrigadas. As evidências dos depósitos sedimentares, nas margens e na área exposta do leito antes inundado, revelam o comprometimento do açude com a erosão e o assoreamento.

Considerando-se a abrangência do tema, tanto sob o ponto de vista geográfico como sob o ambiental, não se tem aqui a pretensão de esgotar o tema da problemática do risco climático da seca, mas a de contribuir para os estudos do semiárido, apontando algumas questões que podem ser relevantes para a contextualização do problema da degradação do solo e da desertificação.

\section{Materiais e Métodos}

0 estudo se fundamenta em pressupostos da morfodinâmica do semiárido, considerando alguns fatores peculiares à Serra do Teixeira, como a irregularidade das precipitações pluviométricas; o regime climático, com estação chuvosa curta; o relevo fortemente ondulado; as áreas com vegetação degradada; a susceptibilidade erosiva dos solos; e o efeito esporádico do escoamento nas encostas.

Para isso foi realizado o levantamento de documentos bibliográfico e cartográfico, além de atividades de campo no entorno da área do Açude de Poços e áreas adjacentes. A pesquisa em livros, artigos e em relatórios de órgãos oficiais e a carta topográfica de Patos (Folha SB -24 - Z D - I, editada pela Superintendência do Desenvolvimento do Nordeste [SUDENE], 1972, em escala 1: 100.000), permitiram a caracterização dos aspectos físicos e ambientais da região; os dados climáticos do município de Teixeira, as imagens disponibilizadas no software Google Earth e os dados de mapas temáticos, deram subsídio para a análise da área de estudo; as visitas ao campo e os registros fotográficos permitiram observar os fatos da real situação estacional do semiárido. Foram realizadas três visitas ao campo, em épocas da estação seca e da estação chuvosa, conforme regime climático da região com chuvas de verão e outono. A primeira visita ocorreu em setembro de 2012, por um período de três dias, a segunda em abril de 2013, por um período de cinco dias, e a terceira em dezembro de 2013 a janeiro de 2014, por um período de oito dias. No campo fez-se o reconhecimento e a localização dos pontos 
de amostragem, sendo fotografados os aspectos da vegetação, do solo, as evidências de processos erosivos e de interferência antrópica.

\section{Situação Geográfica da Área}

De acordo com a divisão regional proposta pelo Instituto Brasileiro de Geografia e Estatística (IBGE), a área de estudo pertence à mesorregião do Sertão Paraibano, que compreende a microrregião Serra do Teixeira, localizada na porção centro-oeste do estado da Paraíba. A Serra do Teixeira, uma superfície de forma alongada com aproximadamente $100 \mathrm{~km}$ de extensão e $10 \mathrm{~km}$ de largura (Sudema, 1994 citado por Agra, Barbosa e Stevens, 2004, p. 125), compreende onze municípios (Água Branca, Cacimbas, Desterro, Imaculada, Juru, Manaíra, Maturéia, Princesa Isabel, São José de Princesa, Tavares e Teixeira).

O município de Teixeira, localizado a leste da serra, na latitude $7^{\circ} 11^{\prime} 10^{\prime \prime}$ 'e $7^{0} 21$ '23"sul e longitude $37^{\circ} 08^{\prime} 22^{\prime \prime}$ e $37^{\circ} 25^{\prime} 33^{\prime \prime}$ a oeste de Greenwich, abrange uma área de aproximadamente $182,20 \mathrm{~km}^{2}$. Limita-se ao norte com os municípios de São José do Bomfim e Cacimba de Areia, a leste com os municípios de Desterro e Cacimbas, a oeste com Matureia e Mãe d'Água, e ao Sul com os municípios do estado de Pernambuco Itapetim e Brejinho (fig. 1). A sede municipal de Teixeira, com altitude em torno de 768 metros, situa-se a uma distância de aproximadamente 298 km de João Pessoa, capital do estado da Paraíba (Serviço Geológico do Brasil [CPRM], 2005).

\section{Caracterização Geográfica e Ambiental}

A Serra do Teixeira pertence ao sistema de relevo do Planalto da Borborema - uma porção do escudo pré-cambriano nordestino que, com sua altitude, exerce influência nos climas de seus diferentes compartimentos geográficos (Melo e Rodrigues, 2004). As rochas magmáticas (granito, migmatito, ultrabásicas) e as metamórficas (gnaisses, anfibolitos, micaxistos, quartizitos) compõem o complexo do embasamento cristalino do Pré-Cambriano (Projeto RADAMBRASIL,1981).

Na mencionada superfície, composta de maciços e blocos falhados com superfícies elevadas, que variam de 700 a 800 metros, destacam-se: elevações com mais de 1.000 metros, que coincidem com algumas cristas e serras com núcleos residuais (inselbergues), como o Pico do Jabre, o mais alto do estado da Paraíba com 1.097 metros de altitude; o nível de aplanamento intermediário da superfície de Teixeira, com resquícios de capeamento sedimentar, situados entre 700 e 800 metros; e o desnivelamento das escarpas oriental $(300 \mathrm{~m}-400 \mathrm{~m})$ e ocidental $(500 \mathrm{~m}-600 \mathrm{~m})$ com suas diferenças climáticas

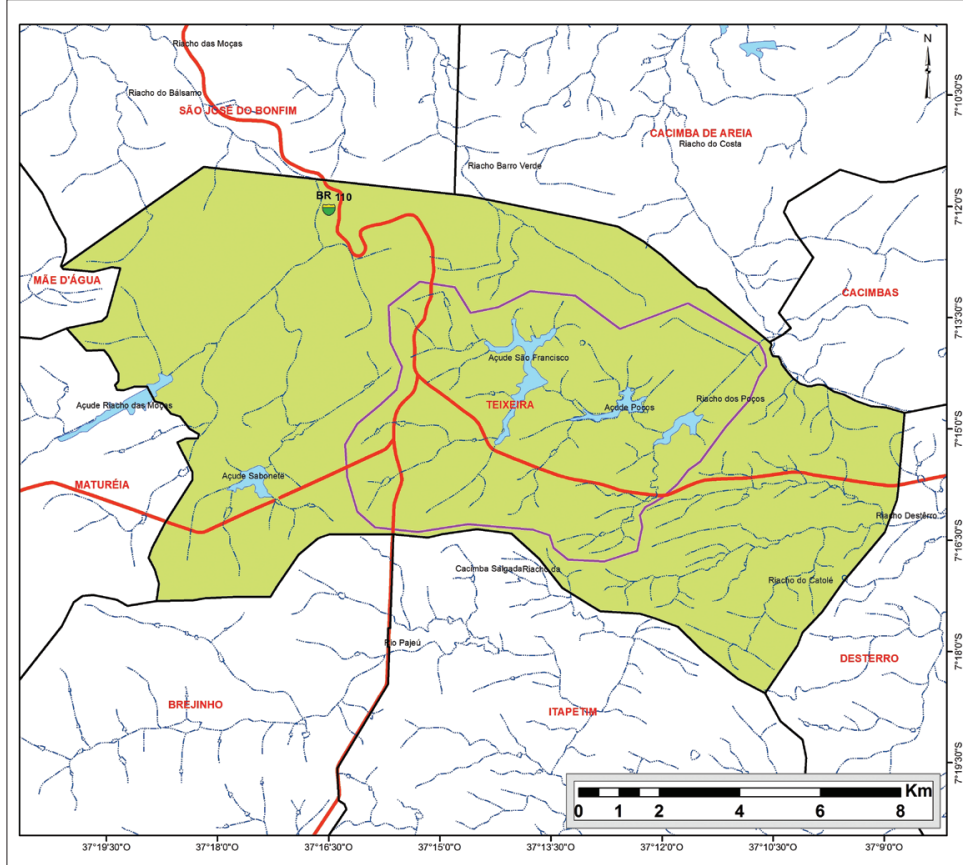

$\bigoplus \quad$ BR

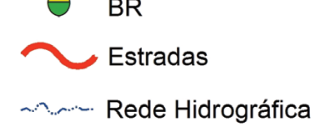

Municípios

Aేrea de Estudo
Município de Texeira

Corpos D' Água

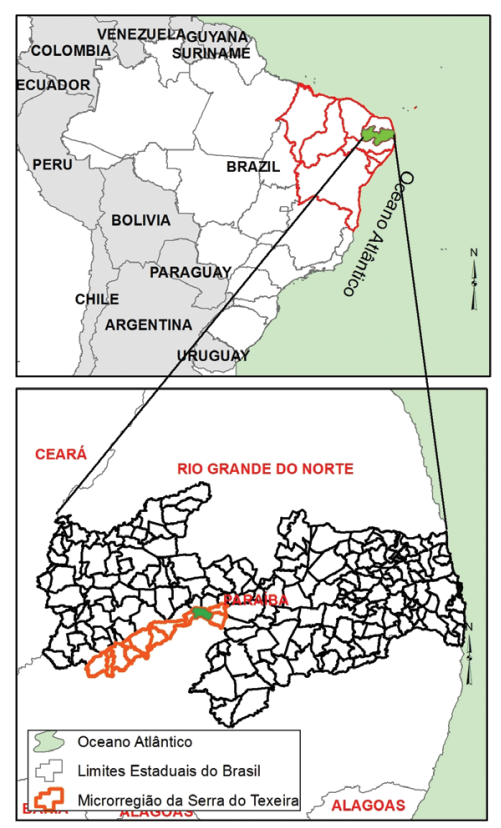

Fonte: Sudene, IBGE e ANA Datum SIRGAS 2000 Zona 24S Elaboração Cartográfica: Maurício Tolstoi

Fig. 1 - Localização do município de Teixeira (Fonte: SUDENE, IBGE e ANA).

Fig. 1 - Location of Teixeira Municipality (Source: SUDENE, IBGE, ANA). 
marcadas pela posição geográfica a barlavento e a sotavento entre as respectivas depressões, a litorânea e a semiárida ( Melo e Rodrigues, 2004). Espessos mantos de alteração recobrem as escarpas a leste, sendo notável no setor oeste "a distinção litológica dos modelados de dissecação diferencial, degraus de soerguimento tectônico e extensas paleossuperfícies regionais de gênese complexa" (Corrêa, Tavares, Monteiro, Cavalcanti e Lira, 2010, p. 37).

A litologia da Serra do Teixeira, conforme Sudema (1994 citado por Agra et al., 2004, p. 125), é representada por biotita, granito e granodiorito, com aspecto típico de granitos e gnaisses. De acordo com Carvalho (1982 citado por Agra et al., 2004, p. 125), o conjunto estrutural apresenta no sentido leste-oeste, uma linha de escarpa muito íngreme, com desníveis da ordem de até $500 \mathrm{~m}$ na face voltada para o pediplano sertanejo. No nível da superfície de Teixeira, o lado leste da serra, conforme J. Santos e Menino (1989), está inserido em dois contextos geomorfológicos: um caracterizado como uma superfície de aspecto colinoso, do pré-cambriano, de relevo suavemente ondulado e escarpado, predominando o relevo fortemente ondulado e montanhoso, com altitude média em torno de 750m; o outro corresponde às formas do capeamento sedimentar do terciário (Formação Serra dos Martins), recobrindo a superfície do embasamento cristalino, com ocorrência de relevo de topo plano e suavemente ondulado das chapadas, presente em algumas áreas da serra, com altitude em torno de 800 a 850 metros. Em tal contexto, os fatores lito-estruturais e erosivos explicam os diferentes níveis altimétricos e o sistema de drenagem da região, representado por alguns riachos, com predominância de padrão dendrítico, como o riacho das Moças, o dos Poços, o do Costa, o do Catolé, entre outros, com fluxo apenas na época chuvosa (CPRM, 2005).

A superfície elevada e as declividades acentuadas, que se diferenciam entre os compartimentos da serra, favorecem a acumulação de água em fundo de vale e represas, como é o caso dos açudes da região: Riacho das Moças, Sabonete, São Francisco II, Poços, entre outros, que além de serem alimentados pelas águas pluviais, são também receptores dos sedimentos levados pelas enxurradas ocasionais do período chuvoso. Conforme Corrêa, J. Souza e Cavalcanti (2014), os barramentos ao longo das drenagens que criam açudes, visando ao armazenamento da água, acabam sendo colmatados, em poucas décadas, devido às altas taxas de produção de sedimentos, resultando no desenvolvimento de planícies antropogênicas, que são utilizadas para cultivo.

\section{Condições Bioclimáticas}

No que diz respeito às ações orográficas, a posição geográfica da serra do Teixeira justifica a variabilidade das precipitações anuais. O clima apresenta modificações em relação a outras áreas do semiárido, devido à geomorfologia, que imprime disposição perpendicular às correntes aéreas dominantes (Lima e Heckendorff, 1985 citado por Agra et al., 2004, p. 125). O fator topográfico, conforme alguns autores (Carvalho, 1982; Cavalcante, 2005; M. Souza e Oliveira, 2006), constitui-se em uma barreira natural aos ventos alísios provenientes do litoral. Os ventos alísios que sopram de sudeste são considerados a fonte de umidade que favorece o município de Teixeira, o qual também se beneficia com menores temperaturas. De acordo com a Classificação de Köppen, a serra do Teixeira enquadra-se no tipo de clima AW'- quente e semiúmido-, com chuvas de verão até o outono (Lima e Heckendorff, 1985 citado por Agra et al., 2004, p. 125). $\mathrm{Na}$ Classificação de Gaussen, utilizada por alguns autores (CPRM, 2005; J. Santos e Menino, 1989), o clima é do tipo 4ath - tropical quente, de seca acentuada.

De acordo com os estudos climáticos realizados por Matos, Medeiros, Silva, Francisco e D. Santos (2015) para o município de Teixeira, com base no balanço hídrico de Thornthwaite (1948) o clima se apresenta como úmido subúmido, mesotérmico, com pequena ou nenhuma deficiência hídrica. A pluviometria média anual é de 753,4 mm (período 1930-2013), com maiores índices nos meses de janeiro a abril e valores mínimos de julho a novembro. A temperatura média anual é de $21^{\circ} \mathrm{C}$, com mínima de $19,8{ }^{\circ} \mathrm{C}$ no mês de julho e máxima de $23,6^{\circ} \mathrm{C}$ em janeiro. A evapotranspiração potencial anual é de 1.051,8 mm, com maiores índices nos meses de novembro a março. A deficiência hídrica ocorre nos meses de setembro a dezembro, com total anual de $421,8 \mathrm{~mm}$ e excedente anual de $123,3 \mathrm{~mm}$, nos meses de março e abril (Matos et al., 2015).

Conforme Sudema (1994 citado por Agra et al., 2004, p. 125), a estação seca dura de cinco a sete meses, de maio a dezembro, atingindo a precipitação de $1 \%$ do total de agosto a outubro. As maiores precipitações ocorrem de janeiro a maio, período em que correspondem a quase $70 \%$ do total anual e a humidade relativa do ar média é de aproximadamente $65 \%$. Nesse contexto, o ambiente geoecológico da serra, onde se insere o município de Teixeira, favorece melhores condições para a agricultura, em relação às outras áreas do semiárido. As regiões serranas, mesmo representando modesta parcela da extensão regional, têm grande importância, por funcionarem como concentradoras de população e como centro de produção agrícola (Andrade, 1998).

Segundo J. Santos e Menino (1989), os cambissolos, os latossolos, os regossolos e os solos litólicos (neossolos litólicos) são os principais tipos de solo encontrados no município de Teixeira. Os cambissolos, associados às áreas de relevo suavemente ondulado e fortemente ondulado, são os mais representativos, ocupando $32 \%$ da área. Suas principais limitações são a susceptilidade erosiva, 
os níveis muito baixos de matéria orgânica e a presença de afloramentos de rocha. Os latossolos ocupam $21 \%$ da superfície de relevo plano a suavemente ondulado, são profundos, apresentam baixa fertilidade e capacidade de armazenamento de água regular a alta. Os regossolos representam 19\% da área de relevo suavemente ondulado, têm baixa capacidade de retenção de água, baixa fertilidade e alta susceptibilidade à erosão, e os solos litólicos (neossolos litólicos), ocupando $28 \%$ da área, são férteis, mas apresentam limitações para uso agrícola, têm pouca profundidade e alta pedregosidade. Com exceção dos litossolos (neossolos litólicos), os outros solos são, em sua maioria, de fertilidade natural baixa ou moderada, praticamente não apresentando limitações para o uso agrícola, salvo a deficiência de água do período de estiagem (J. Santos e Menino, 1989). As espécies de caatinga que recobrem esses solos são do tipo hipoxerófila, com porte e densidade diferentes da vegetação hiperxerófila, a mais seca das caatingas, que é encontrada em outras áreas do semiárido, fora da região serrana, no denominado sertão seco. Nas áreas de relevo mais acidentado, ocorre resquícios da floresta tropical subcaducifólia (fot. 1), como se evidencia no Pico do Jabre - "um enclave de mata serrana no interior da caatinga, apresentando uma vegetação semidecídua, com elementos da mata úmida e da caatinga" (Agra et al., 2004, p. 122). "À medida que se vai descendo as encostas das serras, um pouco distante do divisor de águas, começa a caatinga hiperxerófila, caracterizada por uma fisionomia com predomínio de porte arbustivo,

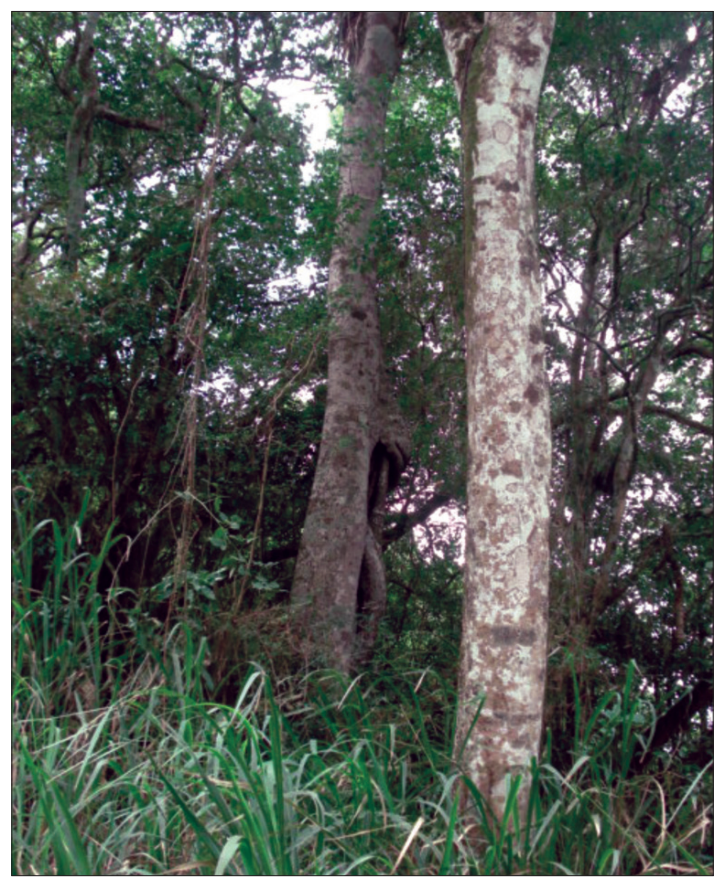

Fot. 1 - Tipo de cobertura vegetal na Serra do Teixeira - encosta do Pico do Jabre 1097m de altitude (Maria Ramalho, janeiro 2010).

Photo 1 - Type of vegetation in Serra do Teixeira - on the slope of Jabre Mountain (Maria Ramalho, January, 2010). com densidade variável e, na maioria das vezes, com substrato rico em cactáceas e bromeliáceas, formando um verdadeiro tapete" (J. Santos e Menino,1989, p.793).

A escassez de chuva muda os aspectos fisionómicos da vegetação e também causa dificuldades, sobretudo para os pequenos agricultores, principalmente quando a estiagem se prolonga e os recursos hídricos favorecidos pelos açudes, tanques, barreiros e poços escavados no leito dos rios ficam escassos ou esgotados. Com as práticas agrícolas próximo das fontes de água, cultiva-se cenoura, tomate, milho, feijão, mandioca e fruteiras, como cajueiro, umbuzeiro, goiabeira, pinheira, cajazeiro - destinados para subsistência e, em geral, para comercialização nas feiras livres.

Segundo Brasil (1991), com a intensificação económica, que se agrava com a estrutura fundiária, os efeitos antrópicos se diversificam, a vegetação é substituída pela atividade agropastoril, o solo perde nutrientes e se degrada com o processo de erosão acelerada. Como enfatiza o autor (p. 102), as culturas irrigadas para a produção de monoculturas, como o tomate e o milho, passam a ser um elo entre os pequenos agricultores e as agroindústrias, inaugurando uma nova fase na agricultura do semiárido, mas confinada a pequenos enclaves.

\section{O Risco Climático da Seca e o Risco Ambiental}

Considerando-se o que é enfatizado por Bento-Gonçalves, Vieira, Costa, Lourenço, Ferreira-Leite e Marçal (2014) ao se referirem aos riscos climático-meteorológicos, cabe aqui mencionar o risco climático da seca no semiárido brasileiro na categoria dos riscos que têm origem na natureza. Segundo Zêzere, Pereira e Morgado (2006), a interação das atividades humanas com o funcionamento dos sistemas naturais conduziu à introdução do conceito de Risco Ambiental, onde se integram fenómenos como a desertificação, poluição e os incêndios florestais.

Nesse contexto, de acordo com Zêzere et al. (2006) o risco é entendido como a probabilidade de ocorrência de um efeito específico causador de danos grave à Humanidade e ao ambiente num determinado período e em circunstâncias determinadas. A natureza de processos e eventos de origem natural ou induzidos por atividades humanas é bastante diversa nas escalas temporal e espacial, por isso o risco natural pode apresentar-se com diferentes graus de perdas, em função da intensidade de abrangência espacial e do tempo de atividade dos processos considerados (Castro, Peixoto e Do Rio 2005). O domínio do risco, como enfatiza Lourenço (2004, p.20), "pressupõe a gestão do risco, o que implica uma planificação global dos riscos que podem afectar uma determinada área, região ou país, para, com base nela se poder proceder a uma planificação integrada dos recursos em função dos riscos". 


\section{A Seca: um fenômeno natural}

No semiárido brasileiro, a seca tem sido entendida como um fenômeno natural decorrente de condições meteorológicas e climáticas que afetam as fontes de água, o solo, a vegetação e a população. De acordo com Campos e Studart (2001), o conceito de seca se relaciona com o ponto de vista do observador. Embora a causa primária seja a insuficiência ou irregularidade das precipitações pluviais - seca climatológica - , a sequência de causas e efeitos afetam o sistema hidrológico (seca hidrológica), o sistema edáfico (seca edáfica), as atividades socioeconómicas (seca social), entre outros aspectos, que podem ser focados com o decréscimo das chuvas. Nesse sentido, convém aqui enfatizar o risco climático da seca como uma realidade perversa para quem avalia a devastação produzida pela estiagem e compreende seus efeitos na paisagem física e no meio socioeconómico e ambiental do sertão nordestino (fot. 2). Nessa região, não só a falta de chuva, mas também a chegada de rigoroso inverno têm seus reflexos principalmente nos campos desprovidos de proteção vegetal. O desflorestamento no entorno das nascentes e topos de serra, deixam descoberto o solo arenoso e pedregoso, sujeito à erosão no período da chuva (Ramalho, 2013).

O risco climático relaciona-se com a variabilidade espacial e temporal das precipitações pluviométricas que negativamente afeta o equilíbrio hidrológico. A interferência das estiagens na vegetação, um tanto agredida pela interferência antrópica, que desmata e queima, desnudando áreas, favorece o rigor dos processos erosivos, sobretudo quando as precipitações pluviais excedem os limites. "São contrastes climatéricos extraordinários", causados pelas prolongadas estiagens e pela superabundância de chuvas, que formam, algumas vezes, correntes devastadoras (Bhering, 1987, p.5),

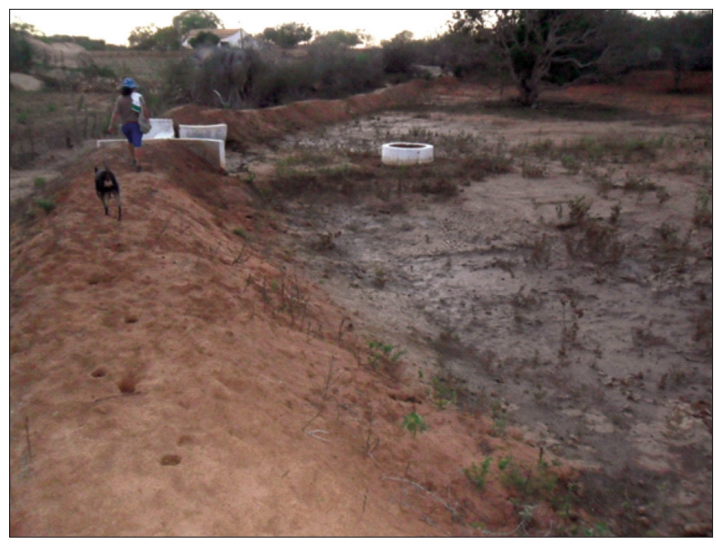

Fot. 2 - Aspectos da paisagem em período de estiagem (2012 -2013) no município de Teixeira, Sitio Poços (Maria Ramalho, 2013).

Photo 2 - Views of the vegetation during the dry season (2012-2013) at Poços in Teixeira Municipality (Maria Ramalho, 2013). as quais arrastam detritos pelas encostas, inundam campos de cultivo, destroem plantações e prejudicam pastagens, suprindo os açudes de água junto com terra, que é conduzida com o escoamento. Assim, tanto os condicionantes climáticos como a interferência humana na cobertura vegetal e nos solos influenciam na vulnerabilidade ambiental à erosão.

De acordo com Ernesto Sobrinho (2014, pp. 57-58), o período normal de estiagem no semiárido do Nordeste brasileiro, "é de 6 a 8 ou 9 meses consecutivos sem chuva, entre o final de junho e o início de março do ano seguinte, podendo ou não ocorrer, nesse intervalo de tempo, chuvas passageiras de baixa a média intensidade e curta duração”. A calamidade de uma seca, conforme esse autor, ocorre com a ampliação desse período normal de estiagem para 18 ou mais meses praticamente sem chuva. A água armazenada na grande maioria dos barreiros e pequenos açudes dificilmente vai além do período de seis meses de estiagem normal anual. A provisão de alimento e de água para o consumo humano e dos animais só ocorre no período chuvoso normal anual. Fora desse período essa provisão fica restrita aos ambientes pontuais dos açudes e rios, quando esses não secam (Ernesto Sobrinho, 2014). Em alguns anos, as chuvas chegam no tempo esperado e, às vezes chove mais do que a média da área considerada (Ab'Saber, 2003). Tem-se aí um fator de risco de erosão, que tanto compromete os solos como os sistemas de abastecimento de água, por causa do assoreamento.

\section{O Ambiente de Impacto da Seca}

A presença de espécies espinhentas, como a jurema (Mimosa stilius Mart.), as cactáceas e as bromeliáceas, e a de plantas herbáceas anuais, caracterizam o aspecto fisionômico da vegetação de caatinga, que, em quase todas as espécies, perde as folhas como meio de resistir à estação seca (Melo e Rodrigues, 2004). No auge da estação seca, quando árvores e arbustos são desfolhados, há uma desoladora impressão de uma vegetação morta (Queiroz, 2006) e, com as condições de insolação, os solos ficam ressecados (esturricados) e mais expostos à ação do escoamento superficial, sobretudo os das encostas (fot. 3).

Na maioria das vezes, a degradação do solo acontece sobre alguma encosta, mas pode ocorrer também em áreas planas. No entanto, as áreas que apresentam alguma declividade são geralmente as mais afetadas (G. Araújo, Almeida e Guerra, 2005). Conforme vários autores (Gerrard, 1992; Selby, 1993; Thornes, 1990; Guerra, 2000 e 2005; Morgan 2005 e Evans, 2006 citado por Guerra, 2014, p. 56) “a erosão dos solos é um fenômeno natural e, dessa forma, todas as paisagens que possuem mais de $3^{0}$ de declividade pode sofrer alguma forma de erosão". 


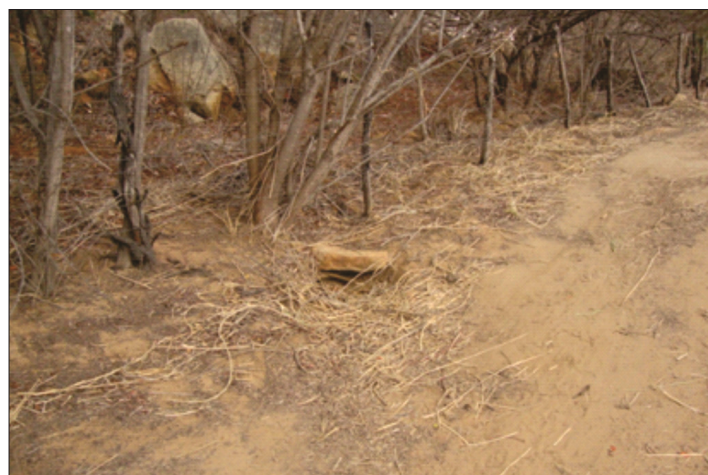

Fot. 3 - Aspecto da vulnerabilidade ambiental aos efeitos das enxurradas com o retorno das chuvas (Maria Ramalho em Teixeira, Sitio Poços, dezembro 2013).

Photo 3 - Views of environmental vulnerability to flash floods as the rains return (Maria Ramalho, in Teixeira, Sitio Poços, December 2013).
Do ponto de vista dos declives, há de se considerar que a maior parte do relevo suavemente ondulado do entorno dos reservatórios em Teixeira (fig.2) têm mais de $3 \%$ de declividade e nas vertentes do relevo ondulado a fortemente ondulado, os declives são acentuados, com valores acima de $45 \%$, como sucede nos divisores de água do riacho dos Poços.

Por se tratar de fundo de vale, compreendendo a área de represamento das águas, é natural a chegada de detritos transportados pelo sistema de drenagem do referido riacho. Sem entrar em grandes considerações sobre os fatores que condicionam os processos erosivos, é importante observar, além da declividade, alguns aspectos relacionados ao comprimento e forma das encostas (convexa-retilínea) da bacia de drenagem. $\mathrm{Na}$ generalidade dos casos, as rupturas de declive entre os divisores de água e a superfície pedimentar, o estado

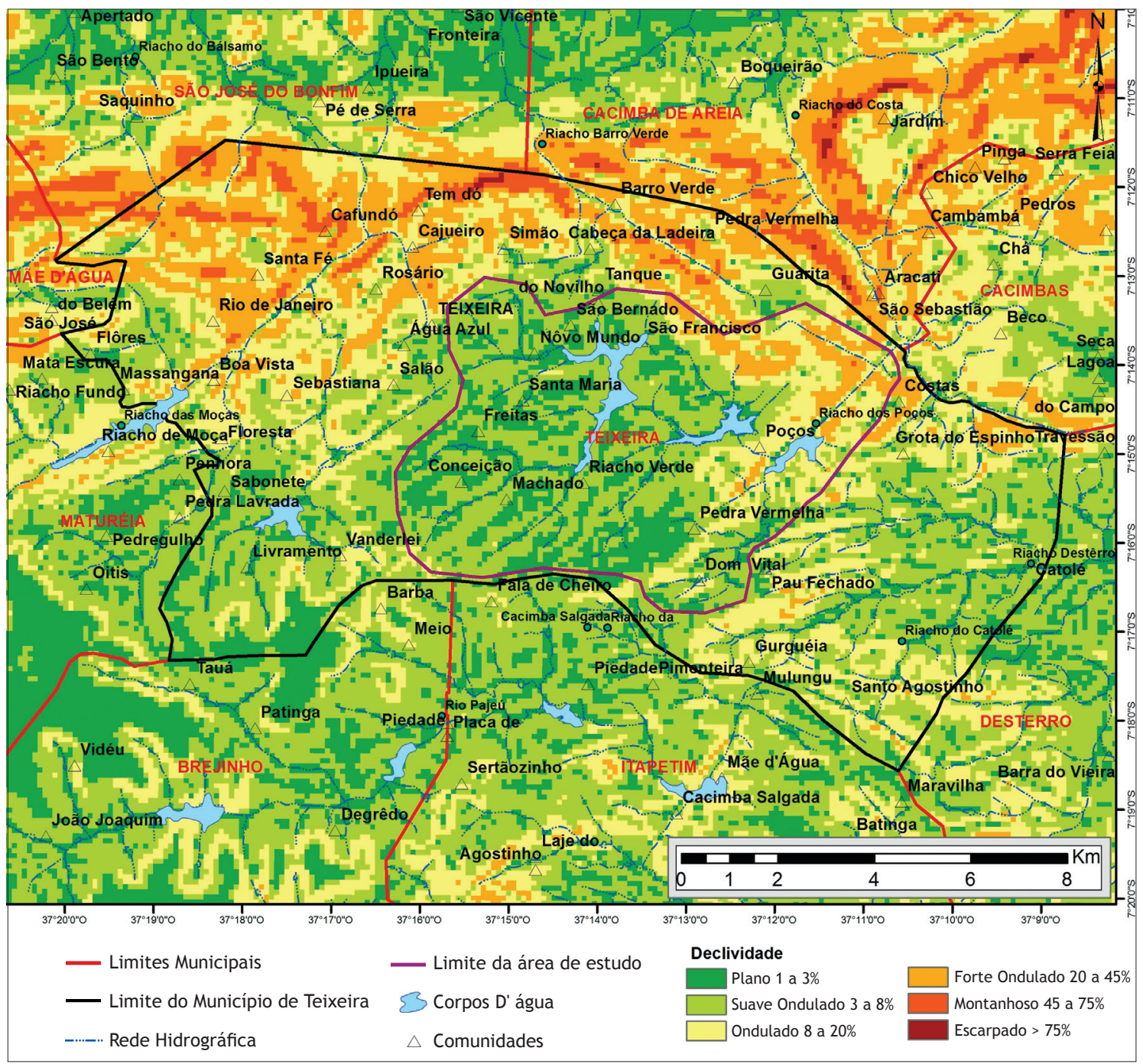

Fig. 2 - Mapa de declividade de ambientes da Serra do Teixeira (Fonte: IBGE, Sudene, CPRM, ANA (Agência Nacional de Água). Elaboração Cartográfica: Maurício Tolstoi, 2015.

Fig. 2 - Slope map for areas of Serra do Teixeira by ANA (National Water Agency, IBGE, SUDENE) Cartographic elaboration: Maurício Tolstoi, 2015. 
da cobertura vegetal, as diferentes situações de uso e manejo da terra e o momento das chuvas concorrem para maior ou menor propensão à atuação erosiva. Nesse sentido, o relevo ondulado e fortemente ondulado (fot. 4) com declividades mais acentuadas (45\%-75\%), atuam como áreas dispersoras de fluxos superficiais, e a água que escoa, na superfície pedimentar pedregosa, pode favorecer condições erosivas restritas às diferentes declividades ao longo das encostas.

Conforme Melo Filho e A. Souza (2006, p. 55), "o risco de degradação física do solo pela erosão é muito elevado quando condições de erosividade e erodibilidade se associam ao relevo acidentado". Nessas circunstâncias (fot. 4), os pontos de inflexão ou de afloramento de rocha separam os segmentos de rampa, que por vezes, se alternam desde os divisores de água até as proximidades dos canais. Dentre os processos superficiais, destaca-se a ação do escoamento superficial difuso não canalizado, sheet-flow, marcado por sua rapidez e forte energia geomórfica (Corrêa et al., 2014). Parsons (1988 citado por Guerra, 2014, p. 27), destaca a importância dos efeitos produzidos pelo escoamento superficial (wash) na erosão dos solos, em que partículas e agregados vão sendo destacados e transportados encosta abaixo. Os efeitos offsit devem-se aos escoamentos de água e sedimentos, causando danos em áreas agrícolas afastadas ou contíguas àquelas onde a erosão ocorre. Esses danos são relacionados a enchentes, assoreamento de rios, de lagos, de reservatórios, e contaminação de corpos líquidos, entre outros (Guerra, 2014).

Com as pesquisas realizadas em parcelas experimentais de erosão no semiárido paraibano, nos municípios de Sumé e São João do Cariri, foi observada a influência da cobertura vegetal, da declividade, da humidade do solo e da prática de cultura sobre o escoamento. Santos et al. (2000 citado por J. Y. Santos et al. (2012. p. 13), realizando estudos em diferentes sistemas de manejo do solo, observaram a

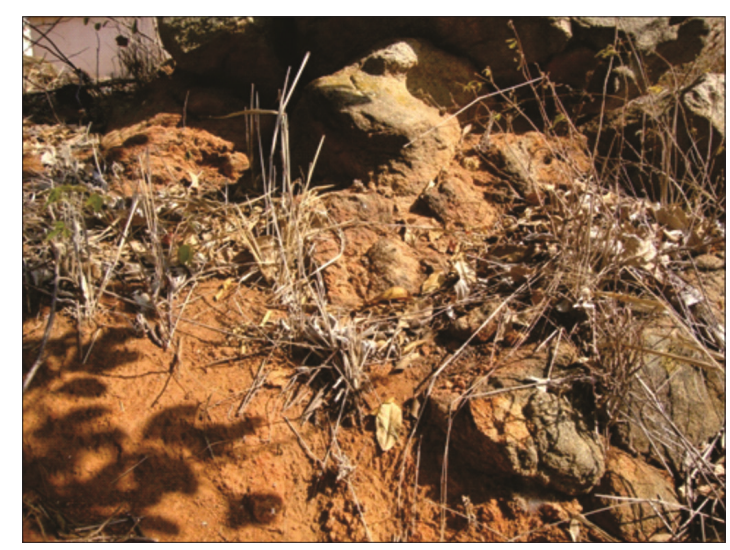

Fot. 4 - Aspecto de uma encosta vulnerável à erosão. Município de Teixeira-PB (Maria Ramalho, 2012).

Photo 4 - Aiews of vulnerability to erosion. Teixeira-PB municipality (Maria Ramalho, 2012). ineficiência da proteção do solo com o cultivo da palma plantada morro abaixo, constatando que a vegetação nativa é o melhor tipo de cobertura para proteger o solo, dentre os tipos por eles estudados.

Com estudos realizados com medição de escoamento superficial e de erosão, Srinivasan, C. Santos e Galvão (2003), constataram que, nas áreas cobertas pela caatinga, as precipitações de até $30 \mathrm{~mm}$ não geravam escoamento superficial e que o significado da proteção podia também ser avaliado com a caatinga regenerada da área em pousio. Como descrevem esses autores ( $p$. 60), "O retardamento do fluxo e o aumento da infiltração no solo, pela existência da vegetação, proporcionam um excelente mecanismo de proteção ao solo raso contra a erosão. Até os eventos de maiores precipitações não produziram erosão nas microbacias com caatinga".

Analisando os tipos de cobertura de solo em relação às condições de humidade, J. Y. Santos et al. (2012) observaram que o aumento da cobertura vegetal no decorrer das chuvas simuladas foi significativa para a redução da produção de sedimentos na parcela com vegetação nativa. Comparando as perdas de solo em diferentes tipos de cobertura vegetal, eles constataram que a vegetação nativa se mostrou eficiente na proteção do solo em relação à parcela desmatada, tendo sido reduzido o escoamento superficial e a produção de sedimentos.

No município de Teixeira, percebe-se que a cobertura vegetal está mais degradada nos espaços agrícolas do entorno dos reservatórios de água e também no da área de interferência urbana (fig. 3). Conforme Leite, L. Araújo, Arriel, Chaves e Nóbrega (2015), a vegetação de caatinga ocupa uma área em torno de 11.760,1 hectares, o equivalente a $64,5 \%$ da área municipal. Nas áreas de relevo mais acidentado, a vegetação está mais preservada, sobretudo nos locais de difícil acesso e impróprios para agricultura. Com as primeiras chuvas torrenciais, destacando-se o estado da cobertura vegetal e a exposição dos solos, maior é a erosão que, progressivamente, tende a ser menor, enquanto a vegetação se regenera.

Quando chegam as primeiras chuvas, árvores e arbustos de folhas miúdas e múltiplos espinhos, tudo reverdece (Ab'Saber, 2003). O ambiente naturalmente se recompõe, mas a preocupação maior se volta para as áreas com vegetação degradada e com interferência antrópica, por causa da erosão acelerada, aumentando cada vez mais a perda de nutrientes do solo e o risco de assoreamento dos mananciais de água. Como enfatiza Ernesto Sobrinho (2014), não havendo degradação do solo pelo uso agrícola nem corte de mato para extração de madeira (lenha, estaca, vara para fazer cerca), a vegetação secundária pode chegar ao clímax, ou coisa semelhante de equilíbrio local num período de 30 anos ou mais. 


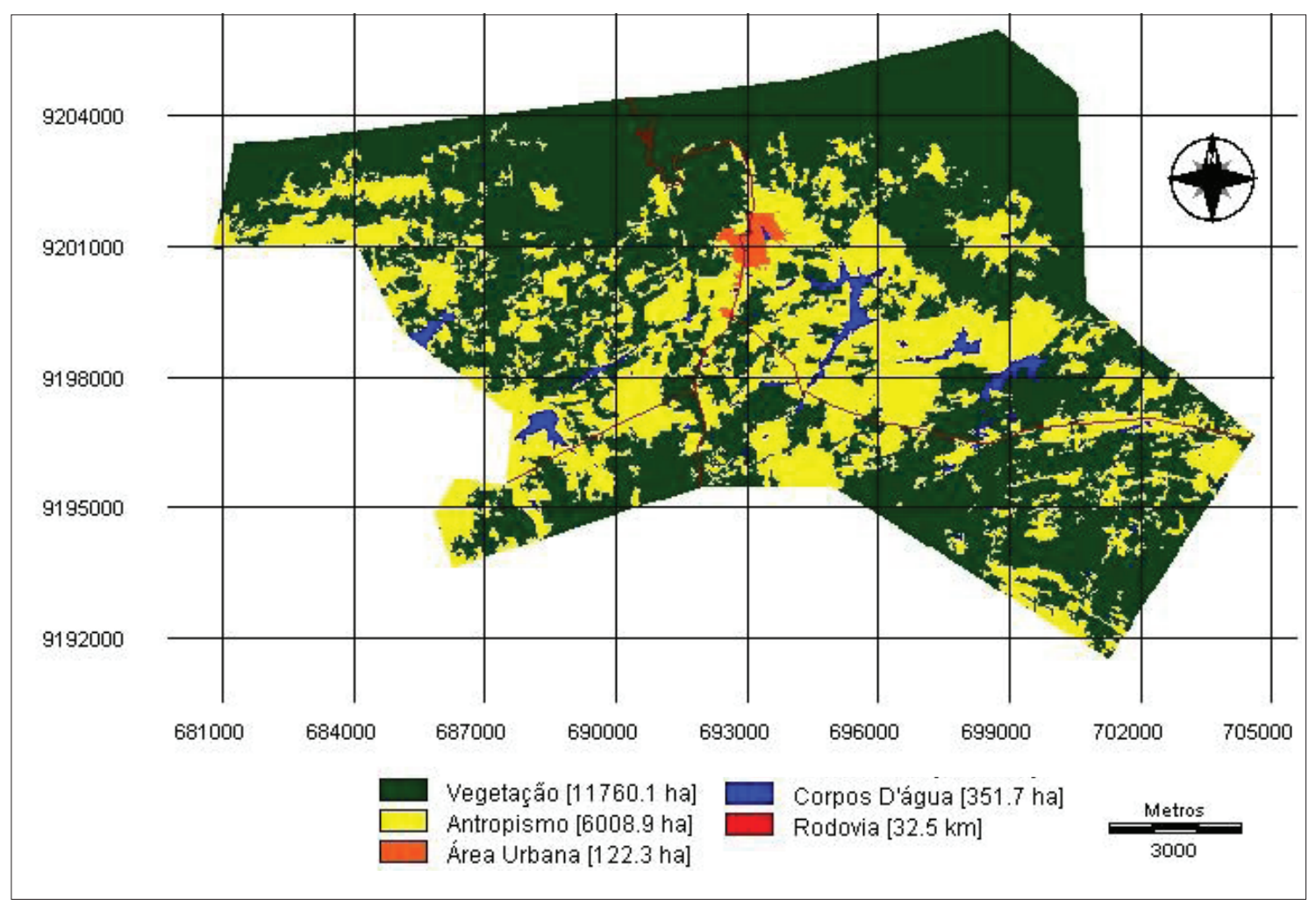

Fig. 3 - Mapeamento da distribuição espacial da cobertura vegetal do município de Teixeira, em novembro de 2008 (Fonte: Leite et al., 2015).

Fig. 3 - Map of the spatial distribution of vegetation in Teixeira Municipality in November, 2008 (Source: Leite et al., 2015.

$\mathrm{Na}$ visão ambiental, os ecossistemas estão sempre se modificando, embora, na maioria das vezes, de forma relativamente lenta, e toda área cujas condições ecológicas favorecem determinadas comunidades ou espécies também sofre alterações. Fatores climáticos, geológicos ou antrópicos podem causar a fragmentação das áreas fazendo surgir entre elas ambientes ecologicamente desfavoráveis à sobrevivência daquelas espécies (Pereira e Almeida, 2000).

Conforme Whittaker (1970 citado por Martins e Rebelo, 2010), os ecossistemas secos geralmente suavizam a pulsação pluviométrica que sobre eles incide. Se existe vegetação nativa, solos profundos, superfície rochosas entre os solos e os profundos vales fluviais, há tendência a se armazenar água, contribuindo para que esses ecossistemas, ao aproximarem-se do seu clímax, controlem cada vez melhor seu próprio microambiente. Mas a ocupação e uso do solo que não consideram a particularidade desses ecossistemas, pode "desencadear um processo de crescente improdutividade dos solos que poderá culminar no processo de desertificação" (Martins e Rebelo, 2010, p. 70). Enfatizam os autores que além do tipo de solo e da declividade das encostas, há as superfícies desnudas e a acção antrópica, que, por vezes, favorecem a erosão hídrica, e também a erosão eólica, podendo assumir um papel muito importante na paisagem e também na dinâmica das vertentes.

No entorno dos mananciais, em Teixeira, apesar de as áreas com maior interferência apresentarem relevo menos acidentado (fig.4), a pouca profundidade do solo (Cambissolo) e a alta pedregosidade confere uma maior vulnerabilidade à superfície que se expõe pela degradação da cobertura vegetal e pelo cultivo da terra. De acordo com WRI et al. (1992, citado por G. Araujo et al., 2005, p. 21), as terras cultivadas podem ser degradadas pela erosão e também por práticas agrícolas, como: a mecanização, que pode favorecer a compactação e selagem do solo; o cultivo sucessivo, que pode esgotar os nutrientes do solo; e a aplicação exagerada de produtos químicos agrícolas, que pode matar os organismos benéficos ao solo. A impermeabilização da superfície, assim como o tipo de solo, a declividade, a interferência do uso e o estado da cobertura vegetal são fatores observados que intervêm na dinâmica erosiva (fot. 5 e 6) e, consequentemente, no assoreamento dos mananciais de água.

Segundo G. Araújo et al. (2005), a degradação de uma unidade de terra pode ser proveniente de condições atmosféricas adversas ou da própria cobertura vegetal 




Fig. 4 - Mapa Hipsométrico do município de Teixeira/Pb (Fonte de dados: IBGE, SUDENE, ANA). Elaboração Cartográfica: Maurício Toistoi, 2014).

Fig. 4 - Hypsometric map of Teixeira, Pb (Data sources: IBGE, SUDENE and ANA). Cartographic elaboration: Maurício Toistoi, 2014.

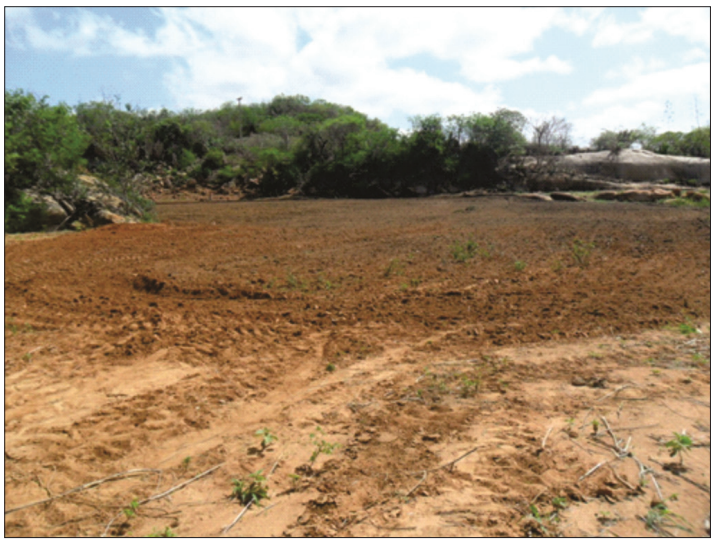

Fot. 5 - Terra arada com trator para plantio (Maria Ramalho, em Teixeira (Sítio Poços), 2013).

Photo 5 - Soil tilled by tractor before planting (Maria Ramalho at Teixeira (Sítio Poços), 2013).

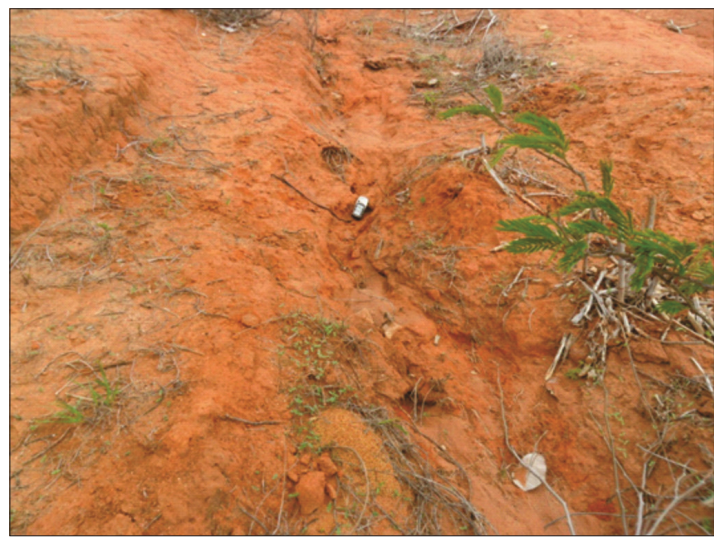

Fot. 6 - Aspectos da encosta com solo compactado e exposto a erosão hídrica (Maria Ramalho, em Teixeira (Sítio Poços), 2014).

Photo 6 - Views of the slope, with compacted soil exposed to water erosion (Maria Ramalho at Teixeira (Sítio Poços), 2014). 
e da população animal (densidade e diversidade), por meio da ação humana, e pode ser agravada por períodos de seca, mais ou menos cíclica, como no Sahel, sudeste da Africa e no nordeste do Brasil. Segundo Blaikie e Brookfield (1987 citado por G. Araújo et al., 2005. p. 31), a degradação da terra e também a seca têm parcialmente sido responsáveis pela severidade da fome em áreas agrícolas da Etiópia e do Sudão. No Egito, conforme Kishk (1986 citado por G. Araújo et al., 2005, p. 40) "a situação da degradação ambiental no Vale do Nilo piorou acentuadamente devido à pressão do crescimento populacional, combinado com a escassez de terras agricultáveis, levando os fazendeiros a exigirem da terra mais do que ela pode produzir".

\section{A Importância do Açude no Semiárido}

No caso do semiárido brasileiro, a valorização dos espaços agrícolas no entorno dos reservatórios de água, geralmente, não observa a vulnerabilidade da área, de modo que não prioriza o planejamento ambiental nas condições de controle de uso e manejo do solo para fins de sustentabilidade. Conhecer os fatores que interferem na dinâmica ambiental é essencial para o ordenamento sustentável e a gestão do uso da água, que, com o crescimento das cidades e o desenvolvimento de culturas mecanizadas, tem sido alvo de uma acentuada pressão sobre os mananciais. Verifica-se que entre os mais proeminentes fatores de degradação da disponibilidade hídrica são o assoreamento e a poluição (J. Araújo, 2012).

J. Araújo (2012, pp. 34-35), avaliando o aporte de sedimentos a sete açudes semiáridos (450 toneladas por $\mathrm{km}^{2}$ de bacia a cada ano), conclui que a taxa de decaimento volumétrico média é de $1,85 \%$ a cada década e que o impacto dessa redução volumétrica sobre a disponibilidade hídrica "é considerável não só pela redução do volume mas por gerar reservatórios de geometria mais aberta, incrementando o já considerável processo de evaporação".

Apesar de outros casos de mananciais de água na Serra do Teixeira com risco de assoreamento, destaca-se o exemplo do Açude de Poços (fot. 7), por ser um dos mais antigos da região, mas de pouca funcionalidade para abastecimento de água nos dias atuais. 0 aumento do cultivo irrigado e a falta de fiscalização para conter o uso excessivo de água no período de estiagem incluem-se entre os fatores que, não apenas nesse Açude, comprometem o sistema de armazenamento de água. Além do mais, a qualidade da água para uso doméstico deixa a desejar, por causa da contaminação por agrotóxico e defensivo agrícola.

$\mathrm{Na}$ área de influência do Açude de Poços (fot. 8), construído com o objetivo de viabilizar o uso da água e solo em condições de semiaridez, incluem-se também as características dos fatores naturais - como a declividade das encostas, as áreas com vegetação degradada, a existência de solos rasos e de afloramentos rochosos, além da compactação do solo -, os quais sob a interferência dos antrópicos, aumentam os rigores do risco ambiental da Seca. Tal risco, porém, só se efetiva por causa da presença humana.

$\mathrm{Na}$ área do substrato cristalino, não há condições de oferta de água subterrânea em quantidade e, às vezes, em qualidade. A oferta superficial feita pelos açudes e, dependendo do volume de água armazenado e das condições de construção dos reservatórios, alguns deles, mesmo sem restituição anual pelas chuvas, fornecem água durante dois ou três anos (Ernesto Sobrinho, 2014). Outros reservatórios, de menor porte, quando não são reabastecidos pelas chuvas, geralmente vão secando ou terminam por secar no período crítico de estiagem.

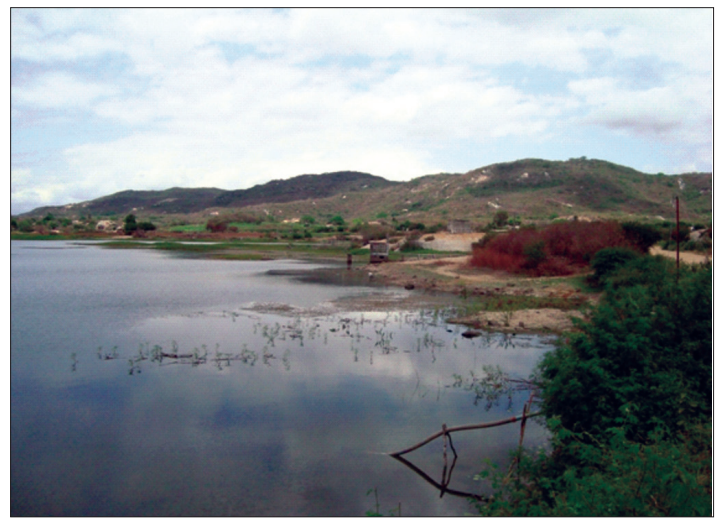

Fot. 7 - Visão parcial do Açude de Poços, antes da longa estiagem, com depósitos de sedimentos no entorno das suas margens (Maria Ramalho, em Teixeira (Sítio Poços), 2009).

Photo 7- Partial view of Poços Reservoir before the long drought, with sedimentation around its banks (Maria Ramalho at Teixeira (Sítio Poços), 2009).

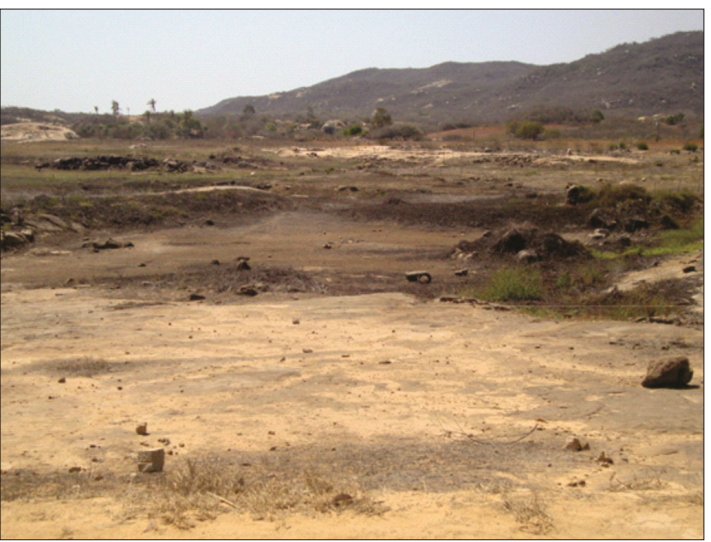

Fot. 8 - Visão parcial do Açude de Poços afetado pela estiagem (Maria Ramalho, em Teixeira (Sítio Poços), setembro 2013).

Photo 8 - Partial view of the Poços Reservoir affected by the drought (M. Ramalho, at Teixeira (Sítio Poços), September, 2013). 
A construção de açudes foi provida no Nordeste em muitas décadas de trabalho do DNOCS (Desenvolvimento Nacional de Obras Contra a Seca). "Estas ações tomadas inicialmente pelo Império e em seguida pelo Governo Federal, remontam ao ano de 1877, ano em que a região foi assolada por uma grande seca" (Campos e Studart, 2001, p. 7).

Segundo Baptista (1933, pp. 179 e 180), na seca 18771879, deu-se o reconhecimento da grande represa de Poços, nos seguintes termos: "O extenso açude no lugar denominado Poços na vila do Teixeira, que atravessa uma área de mais de 300 metros em quadro, prestes a concluir-se sob a direção do Rev. Vo. Bernardo de Carvalho Andrade, que tem se dedicado [...] é uma das obras de maior vulto da Província", e "Obra importantíssima e considerada uma das principais represas d'água do Imperio, a qual muito contribuirá para atenuar, no alto sertão desta Provincia os efeitos de qualquer seca que sobrevenha evitando a reprodução dos males que tem sofrido aquela parte da Provincia por falta de chuva [...]".

A escassez de chuva e os processos naturais da evaporação, o consumo humano e o animal interferem nos sistemas hídricos de abastecimento, mas as atividades agropecuárias, principais recursos econômicos do nordeste semiárido e da Serra do Teixeira (IBGE, 2010), aumentam os riscos de degradação da terra, por causa da erosão, e também o de doenças infectocontagiosas, às vezes causadas pelo uso de águas não adequadas para consumo, tendo-se em vista a qualidade da água represada, que concentra o produto da erosão e dos defensivos agrícolas utilizados nos campos de cultivo.

Com o produto da erosão, que coloca em risco o aterramento do Açude de Poços, a perda de água esvaída pelo sangradouro, todavia, faz-se bem maior. O volume de terra submersa, ao ficar exposto, com o açude seco, revela o efeito das chuvas torrenciais, que favorecem a remoção dos solos para as áreas de baixada (fot. 8). Tal fenómeno, embora de importância para a agricultura nas margens do açude, mais úmidas e mais ricas em nutrientes, também apresenta o inconveniente da deposição de sedimentos, que tende a impossibilitar a disponibilidade do recurso hídrico no período crítico da estiagem.

Uma área com atividade agrícola, onde se encontra o Açude de Poços, o aumento das taxas erosivas põe em risco o desempenho da açudagem, por causa do assoreamento ao longo dos anos. Assim, tem-se diminuída a capacidade do Açude de armazenar um volume maior de águas pluviais e, com a escassez da chuva, a água represada torna-se insuficiente para atender à demanda hídrica do período da estiagem, à proporção que a evaporação e o cultivo irrigado se intensificam. O histórico Açude de Poços, outrora uma obra hídrica necessária para as imprevisões das grandes estiagens, principalmente no sentido de manter as culturas, em torno da área, irrigadas, hoje está ameaçado de desaparecer, devido aos agravantes acima mencionados, que também põem em risco sua longeva existência.

Com os açudes, como recurso de armazenamento de água, certamente a sazonalidade do semiárido pode ser menos agressiva. Durante a cessação da chuva, os campos arborizados ou cobertos de lavoura e relva aparecem como sem vida, mas a área descoberta dos açudes que secam mantém a umidade por mais tempo e a vegetação de vazante beneficia o gado solto pelos campos. No entanto, o assoreamento dos açudes por causa da erosão é também uma realidade das grandes represas de água, que terminam por diminuir seu tempo de utilidade.

\section{Considerações Finais}

Os riscos associados à seca tornam-se críticos nas áreas semiáridas, considerando-se que a interferência antrópica e o déficit hídrico do período de estiagem, consorciados aos fatores naturais - do relevo, das condições climáticas, dos solos, da natureza da cobertura vegetal -, e à necessidade de sobrevivência dos habitantes são fatos reais que não podem ser mudados. Mas o risco ambiental talvez só possa ser reduzido com a mudança de mentalidades. Nesse aspecto, o fenómeno meteorológico é causado pela ordem natural dos sistemas atmosféricos, e o risco das secas se remete à história da ocupação da referida área. $\mathrm{O}$ uso predatório há mais de quatro séculos e os diferentes graus de agressão ao meio natural são questões levantadas por vários autores que analisam as causas ambientais do Nordeste semiárido, bem como as da desertificação. Mas, no atual estágio de desenvolvimento da região, é quase impossível mudar mentalidades senão pelo trabalho de sensibilização e de conscientização, principalmente com as práticas de Educação Ambiental.

Sob o ponto de vista climático e o geográfico da área de impacto da seca, toda e qualquer discussão sobre o assunto é ainda insustentável, carecendo-se de estudos mais aprofundados sobre a causa ambiental que envolvam pesquisas que priorizem uma investigação mais exaustiva sobre a erosão e a degradação dos solos na Serra do Teixeira e outras áreas com problemas idênticos. Nesse aspecto, a ocorrência de eventos de seca e de chuva mostra a necessidade de estudos geomorfológicos e climáticos para uma melhor compreensão dos processos morfogenéticos e para que a gestão pública estabeleça planos de acção, que priorizem o meio ambiente, em diferentes formas de utilização dos recursos naturais. Combater a degradação da vegetação causada pela interferência antrópica pode ser a forma mais eficaz de se amenizar o efeito da erosão acelerada e de vir-se a poder conservar por mais tempo a água nas fontes, além de se melhorar a qualidade da água dos mananciais, contaminada por agrotóxicos e fertilizantes químicos. 
Do exposto, conclui-se que:

- Os efeitos da seca são severamente sentidos em sua magnitude, mas passado o risco hidrológico tudo tende a voltar à normalidade com o retorno das chuvas, e também com as mesmas práticas de manejo do solo;

- A vulnerabilidade da região aos eventos de seca configura risco natural, mas a degradação por causa de interferência humana aumenta o risco ambiental;

- $\quad$ assoreamento dos açudes aumenta as dificuldades económicas da população que convive com os riscos da seca;

Assim, numa visão preliminar dos fatos analisados neste trabalho, tanto o fator climático como o antrópico podem causar risco ambiental para a região, sendo o primeiro um processo natural e o segundo causado pela sequência de intervenções humanas sem controle de preservação e conservação dos recursos naturais.

\section{Referências Bibliográficas}

Ab'Saber, A. N. (2003). Os Domínios de Natureza no Brasil: Potencialidades Paisagísticas. São Paulo: Ateliê Editorial, 159p.

Agra, M. F. de, Barbosa, M. R. V. e Stevens, W. D. (2004). Levantamento Florístico Preliminar do Pico do Jabre, Paraiba, Brasil. In: K. C. Pôrto, J. J. P. Cabral; M. Tabarelli (Orgs.). Brejos de Altitude em Pernambuco e Paraíba - História Natural, Ecologia e Conservação (pp. 122-138). Brasília: MMA/UFPE.

Andrade, M. C. de (1998). A Terra e o Homem no Nordeste (6a ed). Recife: Editora Universitária da UFPE, 305p.

Araújo, G. H. S., Almeida, J. R. e Guerra, A. J. T. (2005). Gestão ambiental de áreas degradadas. Rio de Janeiro: Bertrand Brasil.

Araújo, J. C. de (2012). Recursos Hídricos em Regiões Semiáridas. In: H. R. Gheyi, V. P. da S. Paz, S. de S. Medeiros e C. de O. Galvão (Orgs.), Recursos Hídricos em Regiões Semiáridas: Estudos e Aplicações. Instituto Nacional do Semiárido (pp. 30-43). Campina Grande: Insa, UFRB. ISBN 978-85-64265-03-5. Disponível em: http://www.insa. gov. br/ wp- content/themes/ insa_ theme/acervo/recursos-hidricos-II.pdf

Baptista, P. (1933). O Cônego Bernardo. Rio de Janeiro: Civilização Brasileira, 211 p.

Bento-Gonçalves, A., Vieira, A., Costa, F. , Lourenço, L., Ferreira-Leite, F. e Marçal, V. (2014). Manifestação de Riscos no NW de Portugal. Riscos, Associação Portuguesa de Riscos, Prevenção e Segurança. Livro Guia da Viagem de Estudo, III Congresso Internacional, I Simpósio Ibero-Americano, VIII Encontro Nacional de Risco, Guimarãs-PT.
Bhering, F. (1987). O problema do Norte. In: V. Rosado e A. Rosado (Orgs.), Décimo sexto livro das secas (Coleção Mossoroense, vol. CCCLXXVIII, p. 5-41). São Paulo: Instituto de Geografia da Universidade de São Paulo.

BRASIL. PRESIDÊNCIA DA REPÚBLICA (1991). O Desafio do Desenvolvimento Sustentável. Relatório do Brasil para a Conferência das Nações Unidas sobre Meio Ambiente e Desenvolvimento. Brasília, CIMA, 204 p.

Campos, J. N. e Studart, T. M. C.(2001). Secas no Nordeste do Brasil: Origens, Causas e Soluções. Disponível em: http://www.deha.ufc.br/ticiana/ Arquivos/Publicacoes/Cogressos/2001/Secas_no_ Nordeste_do_Brasil_08_de junho def.pdf. Acesso em: 08/05/2016.

Carvalho, M. G. R. F. (1982). Estado da Paraíba: classificação geomorfológica. João Pessoa: Ed. Universitária/UFPB.

Castro, C. M. de, Peixoto, M. N. de Oliveira e Do Rio, A. P. (2005). Riscos Ambientais e Geografia: Conceituações, Abordagens e escalas. Anuário do Instituto de Geociências-UFRJ, 28 (2), 11-30. ISSN0101-9759.

Cavalcante, A. (2005). Jardins suspensos no Sertão. Scientific American Brasil, 32. Disponível em: https://pt.slideshare.net/MCTI/jardins-suspensos

Corrêa, A. C. B., Souza, J. O. P. de e Cavalcanti, L. C. de S. (2014). Solos do Ambiente Semiárido Brasileiro: erosão, degradação a partir de uma perspectiva geomorfológica. In: A. J. T. Guerra e M. C. O. Jorge (Orgs.), Degradação dos solos no Brasil (p. 127-169). Rio de Janeiro: Bertand Brasil.

Corrêa, A. C. B., Tavares, B. A. C., Monteiro, K. de A., Cavalcanti, L. C. de S. e Lira, D. R. de (2010). Megageomorfologia e Morfoestrutura do Planalto da Borborema. Revista do Instituto Geológico, São Paulo, 31 (1/2), 35-52.

Ernesto Sobrinho, F. (2014). Ecossistema Agrícola no Semiárido na Trilha da Memória. Mossoró: Fundação Vingt um Rosado, 408p.

Guerra, A. J. T. (2014). Degradação dos Solos. Conceitos e Temas. In: A. J. T. Guerra e M. C. O. Jorge (Orgs.). Degradação dos solos no Brasil (pp. 15-50). Rio de Janeiro: Bertand Brasil.

INSTITUTO BRASILEIRO DE GEOGRAFIA E ESTATÍSTICA (2010). Paraíba. Teixeira. Disponível em: http://cidades.ibge. gov. br/xtras/perfil.php? codmun=251670

INSTITUTO NACIONAL DO SEMIÁRIDO. (2012). Sinopse do Censo Demográfico para o Semiárido Brasileiro. Campina Grande. Disponível em: http//www.insa.gov.br/censosab/index.php? 
Leite, J. A. N., Araújo, L. V. C. de, Arriel, E. F. , Chaves, L. F. C. e Nóbrega, A. M. F. da (2015). Análise quantitativa da vegetação lenhosa da caatinga em Teixeira, PB. Brazilian Journal of Forestry Research, 35 (2). Disponivel em: http://pfb.cnpf.embrapa.br/pfb/index.php/pfb/ article/view/584. Doi: http://dx.doi.org/10.4336/2015. pfb.35.82.584

Lourenço, L. (2004). Riscos Naturais e Proteção do Ambiente. Coimbra: Gabinete de Publicações da FLUC, Núcleo de Investigação Científica de Incêndios Florestais, 178 p.

Martins, B. e Rebelo, F. (2010). Erosão e paisagem em São Vicente e Santo Antão (Cabo Verde): 0 risco de desertificação. Territorium, Portugal, 16, 69-78.

Matos, R. M. de, Medeiros, R. M. de, Silva, P. F. da, Francisco, P. R. M. e Santos, D. (2015). Caracterização Agroclimática e Aptidão Climática de Culturas para Teixeira. Congresso Técnico Científico da Engenharia e da Agronomia -CONTEC. Centro de Eventos do CearáFortaleza-CE.

Melo, A. S. T. e Rodrigues, J. L. (2004). Paraiba: desenvolvimento econômico e a questão ambiental. João Pessoa: Editora Grafset, 164p.

Melo Filho, J. F. e Souza, A. L. V. (2006). O manejo e a conservação do solo no semi-árido baiano: desafios para a sustentabilidade. Bahia Agric., 7 (3), 50-60.

Mendes, Benedito V. (1985). Alternativas tecnológicas para a agropecuária do semiárido (Projeto Nordestino, Coleção Mossoroense). Rio de Janeiro, Rede Globo.

Pereira, J. B. S. e Almeida, J. R. de (2000). Biogeografia e Geomorfologia. In: A. J. T. Guerra e S. B. Cunha (Orgs.), Geomorfologia e Meio Ambiente (pp. 195247). Rio de Janeiro: Bertrand Brasil.

PROJETO RADAMBRASIL (1981). Levantamento de Recursos Naturais. Folhas SB. 24/25 Jaguaribe/Natal (23), Rio de Janeiro, 740p.

Queiroz, L. P. (2006). Angiosperma do Semi-árido Brasileiro. In: L. P. Queiroz, A. Rapini e A. M. Giulietti (Eds.), Resumo ao amplo conhecimento da biodiversidade do semi-árido brasileiro (Cap. 6, p. 47-52). BrasíliaBrasil, Ministério da Ciência e Tecnologia.
Ramalho, M. F. J. L. (2013). Risco em ambiente semiárido: uma revisão da recorrência da seca no nordeste dos Brasil. Disponível em: http://www.uc.pt/fluc/depgeo/ publicacoes/livro_homenagem_FRebelo/339-350

Sá, I. B., Cunha, T. J. F., Teixeira, A. H. C. T. , Angelotti, F. \& Drumond, M. A. (2010). Desertificação no Semiárido brasileiro. Fortaleza. ICID+18, $2 a$ Conferência Internacional: Clima, Sustentabilidade e Desenvolvimento em Regiões Semiáridas, 16 - 20 de Agosto de 2010, Fortaleza - Ceará, Brasil.

Santos, J. B. e Menino, I. B. (1989). Avaliação dos recursos naturais do município de Teixeira na Paraíba. Disponível: http://marte.sid.inpe.br/col/ dpi.inpe.br/marte@80/2008/08.19.44/dos/791-796. pdf. Acesso em: 08/05/2016.

Santos, J. Y. G. dos, Santos, C.A. G. , Silva, R. M. da, Lima, V. C. de, Silva, L. P. e Arruda, P. M. (2012). Análise das Perdas de Água e Solo no Semiárido Paraibano utilizando Simulador de Chuva. XIX Simpósio Brasileiro de Recursos Hídricos, Maceió. Disponível em: http://www.abrh.org.br. doi:10.21168/rbrh. v17n4.p217-228

SERVIÇO GEOLÓGICO DO BRASIL (2005). Diagnóstico do Município de Teixeira, estado da Paraíba. Recife, CPRM/PRODEEM, Projeto Cadastro de Fontes de Abastecimento por Água Subterrânea. 10 p.

Souza, M. J. N. e Oliveira, V. P. V. (2006). Os enclaves úmidos e subúmidos do semiárido do Nordeste brasileiro. Mercator- Revista de Geografia da UFC, 5 (9) 85-102.

Srinivasan, V. S., Santos, C. A. G. e Galvão, C. O. (2003). Erosão Hídrica do Solo no Semi-arido Brasileiro: A Experiência na Bacia Experimental de Sumé. RBRH Revista Brasileira de Recursos Hídricos, 8 (2), 57-73.

SUPERINTENDÊNCIA DO DESENVOLVIMENTO DO NORDESTE (1972). Carta Topográfica à escala 1:100.000. Cruzeiro do Sul, Rio de Janeiro. Folha Patos SB.24-Z-D-I.

Zêzere, J. L., Pereira, A. R. e Morgado, P. (2006). Perigos Naturais e Tecnológicos no Território de Portugal Continental. In: Apontamentos de Geografia.Lisboa, série: Investigação, Centro de Estudos Geográficos. 